\title{
Frugivory and seed dispersal by birds in Cereus jamacaru DC. ssp. jamacaru (Cactaceae) in the Caatinga of Northeastern Brazil
}

\author{
Gomes, VGN. ${ }^{\mathrm{a}, \mathrm{b} *}$, Quirino, ZGM. ${ }^{\mathrm{b}}$ and Araujo, HFP. ${ }^{\mathrm{c}}$ \\ aPrograma de Pós-graduação em Biologia Vegetal, Departamento de Botânica, Universidade Federal de Pernambuco - UFPE, \\ Rua Prof. Nelson Chaves, s/n, Cidade Universitária, CEP 50670-901, Recife, PE, Brazil

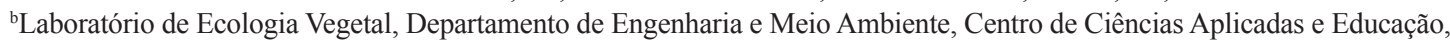 \\ Universidade Federal da Paraíba - UFPB, Rua da Mangueira, s/n, Centro, CEP 58297-000, Rio Tinto, PB, Brazil \\ 'Departamento de Ciências Biológicas, Centro de Ciências Agrárias, Universidade Federal da Paraíba - UFPB, Campus II, \\ Rod. PB-079, s/n, Cidade Universitária, CEP 58397-000, Areia, PB, Brazil \\ *e-mail: vannobrega@yahoo.com.br
}

Received: July 31, 2012 - Accepted: January 15, 2013 - Distributed: February 28, 2014

(With 2 figures)

\begin{abstract}
Studies of the dispersal modes of plants aid our understanding of the dynamics of resource and its availability for dispersal agents. The present work sought to characterize the fruiting patterns of the native Caatinga (dryland) cactus Cereus jamacaru, identify its principal dispersers, and evaluate the effects of seed passage through digestive tract of dispersers on its germination. Cereus jamacaru present an annual fruiting pattern and fruiting peaks occurred during June/2009 and February/2010. A total of 135 visits by nine species of resident Caatinga bird species were recorded. The most frequent visiting bird species were Paroaria dominicana and Euphonia chlorotica. Length of bird visits varied from 15 seconds to 4 minutes and seeds removed by birds travelled $10.6 \pm 11.2 \mathrm{~m}$ until dispersers make the first landing perch, in some cases more than 40 meters away. Germination tests show birds had a high quantity of viable seeds of C. jamacaru in its feces. Seeds that passed through the digestive tract of birds showed a similar germinability of the seeds of the control group. However, the seeds dispersed by birds showed lowest mean germination time related to the control group seeds. This study highlights the potential role of birds as seed dispersers of C. jamacaru, swallowing the whole seeds and defecating intact seeds, accelerating the germination process and transporting seeds away from the mother plant.
\end{abstract}

Keywords: frugivores, seed germination tests, phenology, ornithochory.

\section{Frugivoria e dispersão de sementes por aves em Cereus jamacaru DC. ssp. jamacaru (Cactaceae) na Caatinga, uma floresta seca no Nordeste do Brasil}

\section{Resumo}

Estudos do modo de dispersão das espécies vegetais permitem o entendimento da dinâmica dos recursos e sua disponibilidade para os dispersores. O objetivo deste trabalho foi caracterizar o padrão de frutificação de Cereus jamacaru, uma espécie nativa da Caatinga, identificar os seus principais dispersores e avaliar o efeito da passagem das sementes pelo trato digestivo destes animais sobre sua germinação. Cereus jamacaru apresentou um padrão de frutificação anual, com pico de frutificação nos meses de Junho/2009 e Fevereiro/2010. No total foram registradas 135 visitas de nove espécies de aves frugívoras da Caatinga, sendo os dispersores mais frequentes Paroaria dominicana e Euphonia chlorotica. O tempo de duração das visitas foi curto, variando de 15 segundos a 4 minutos, e a distância média dos voos pós-alimentação foi 10,6 $\pm 11,2 \mathrm{~m}$ da planta-mãe, podendo também alcançar distâncias superiores a 40 metros. Os resultados dos testes de germinação mostraram que as aves apresentam uma alta quantidade de sementes viáveis de C. jamacaru em suas fezes. As sementes que passaram pelo trato digestivo das aves mostraram germinabilidade semelhante aquelas do grupo controle. No entanto, as sementes dispersadas pelas aves apresentaram um menor tempo médio necessário para germinação. Esse estudo destaca o papel das aves como potenciais dispersores de C. jamacaru, eliminando sementes intactas, acelerando o processo de germinação e carregando as sementes para longe da planta mãe.

Palavras-chave: frugívoros, germinação, fenologia, ornitocoria. 


\section{Introduction}

Seed dispersal is an important stage in the reproductive cycle of most plants (Wenny and Levey, 1998). Seed dispersal by frugivorous animals constitutes a symbiotic process in which plant diaspores are dispersed usually in exchange for nutritional rewards in the form of fleshy pericarps (Van der Pij1, 1982; Coates-Estrada and Estrada, 1988). This type of plant-animal mutualism represents a much more complex relationship than a simple exchange of advantages and is influenced by many factors (Howe and Smallwood, 1982), including environmental conditions, fruiting phenology, and the efficiency of the dispersal agent.

Dispersal success depends directly on the feeding behavior of the frugivore, fruit processing, and postfeeding movements (Jordano and Schupp, 2000). Seed disperser birds have many distinct characteristics that influence their dispersal efficiency, including variations in their behavioral patterns and seed retention times, their digestive processes, and mode which seeds are subsequently deposited in the environment; all of these factors will influence the reproductive success of plants (Herrera and Jordano, 1981; Moermond and Denslow, 1985).

Studies on frugivory have been carried out in a variety of environments, most of these being humid forests. However, the arid and semiarid ecosystems of the world have received little attention (Jordano, 1992). Semiarid ecosystems in the Neotropics have a great variety of columnar cacti that produce a large biomass of fleshy fruits that produce a large biomass of fleshy fruits with a high sugar content and water (Sosa, 1991). In the northeast semiarid of Brazil, Cactaceae represents a widely distributed family in Caatinga (Taylor and Zappi, 2004), being one of the top four species-rich plant families in the ecosystem (Rodal and Sampaio, 2002). Many species of Cactaceae show reproductive activities not directly dependent on rainfall patterns (Petit, 2001), offering resources to pollinators and dispersers independent of the precipitation - being considered key-species that can sustain the frugivorous vertebrate community during periods of extreme scarcity of other food resources (Terborgh, 1986).

Fruits of Cactaceae are generally fleshy with a great number of seeds embedded in a structure that is denominated funicular pulp (Taylor and Zappi, 2004). These fruits constitute an important resource for different groups of animals, such as birds, insects, reptiles, and mammals, that can manipulate and/or ingest seeds and transport them without damages, therefore contributing to its germination in sites distant from the mother plant (Silva, 1988; León de la Luz and Domínguez, 1991; Silvius, 1995; Soriano et al., 1999; Ruiz et al., 2000; Godinez-Alvarez et al., 2002; Naranjo et al., 2003; Carlos Rengifo et al., 2007).

Cereus jamacaru DC. is a native Caatinga Cactaceae species well-adapted to the semiarid conditions of northeastern Brazil and is generally common throughout that region (Freire, 2009). Relatively few studies have focused on this taxon in spite of its importance to the ecology of the Caatinga region, addressing issues related to reproductive phenology, secondary dispersal and seed germination (Quirino, 2006; Andrade et al., 2006; Leal et al., 2007; Meiado et al., 2010). C. jamacaru demonstrates annual flowering and fruiting related to seasonal rainfall, with a zoochorous dispersal syndrome (Quirino, 2006; Leal et al., 2007). Although fruits have zoochorous characteristics, which animal species are responsible for this species seed dispersal remains to be verified. What is the effect of seeds passage through the digestive tract of dispersers? The present study was designed to answer these questions and characterize the fruiting pattern of Cereus jamacaru. Also, we aimed to identify the principal fruit consumers and examine their potential as seed dispersers.

\section{Material and Methods}

\subsection{Study area}

The present study was undertaken at a private natural reserve (PNR) at Fazenda Almas ( $7^{\circ} 28^{\prime} 15^{\prime \prime} \mathrm{S}$ and $36^{\circ} 52^{\prime}$ $51^{\prime}$ W), which has an area of 3.505 hectares and is located largely in the municipality of São José dos Cordeiros, with a small section in the municipality of Sumé, in Paraiba state (PB), Brazil. The reserve is localized in the Cariri Paraibano region, region with the lowest rainfall levels in the Caatinga zone of PB. Climate of the region is characterized by extreme conditions such as high radiation, low relative humidity and cloudiness, and high average annual temperature, varying from 26 to $33{ }^{\circ} \mathrm{C}$ (Prado, 2003). Annual average precipitation levels are less than $600 \mathrm{~mm}$ and quite irregular; regional climate is classified as 'warm semiarid' (Bsh) with summer rains, according to the Köppen system (Köppen, 1948). The PNR is dominated by both dense and open arboreal habitats of Caatinga vegetation, with other specific open habitats such as rock outcrops ("lajedos") with their distinctive floras, and small sandy areas ("campestres") scattered among the arboreal formations (Barbosa et al., 2007).

\subsection{Study species}

Cereus jamacaru DC. ssp. jamacaru (Cactaceae) is a widely distributed species, both in natural and anthropic areas (Anderson, 2001). This species is a columnar cactus locally known as 'mandacaru' that belongs to the tribe Cereeae which comprises approximately 35 species (Anderson, 2001), used as forage, as an ornamental plant, and in popular medicine (Andrade et al., 2006). Cereus jamacaru plants are treelike plants with distinct trunks of up to $60 \mathrm{~cm}$ in diameter and many erect branches, forming dense crowns with up to $10 \mathrm{~m}$ height. The flowers are solitary, nocturnal and white; its pollination syndromes apparently involve sphingophily and chiropterophily (Quirino, 2006). The fruits are ellipsoidal, with 5-12 cm in length, and $7-12 \mathrm{~cm}$ in diameter, with red epicarp, white pulp (Anderson, 2001), and black seeds, which are secondarily dispersed by ants (Leal et al., 2007). Cereus jamacaru is classified as a positive photoblastic species and optimum temperature for seed germination is $30{ }^{\circ} \mathrm{C}$ according to Meiado et al. (2010). 


\subsection{Methodology}

We carried out monthly phenological monitoring in fifteen individuals of C. jamacaru from March/2009 to August/2010, through direct count of fruits produced by each individual that grow next to pre-existing trails (and separated from one another by at least $30 \mathrm{~m}$ ). Fruits were grouped into three fruiting phases: unripe, ripe and dispersed (according to Soriano et al., 1999). The phenological patterns were identified following the classification system proposed by Newstrom et al. (1994). The Synchrony Index was calculated according to Augspurger (1982) to determine the synchronicity level of fruiting in this species.

The morphological characteristics of $C$. jamacaru fruits such as fruits and seeds sizes, weight, pulp consistency, fruit type, and degrees of dehiscence were analyzed in the Laboratório de Ecologia Vegetal at Universidade Federal da Paraiba - UFPB. Measures of ripe fruits and seeds sizes (diameter and length) were made with digital caliper, and weight of seeds and fruits were accessed with a precision scale. Only a single ripe fruit from each sampled plant individual was used to calculate measurements means and standard deviations.

During months of fruiting peak, observations of seed dispersers were made on nonconsecutive days, from 05:00 to 17:00 $\mathrm{h}$ through focal observations (aided by binoculars) of individual bearing ripe fruits, totaling $148 \mathrm{~h}$ of observation. It was also realized observations during the night period $(\mathrm{N}=24 \mathrm{~h})$ and in rainy days $(\mathrm{N}=24 \mathrm{~h})$. All focal observations were made at a distance of about $8 \mathrm{~m}$ of the focal plant and were complemented by photographic records of frugivores to help species identification. This distance was chosen to avoid any influence in the behavior of birds during visits.

During each visit we recorded bird species and number of visitors, and the exact time and duration of each visit. Visiting frequencies of each bird species were calculated according to Gondim (2001) and Pascotto (2006), dividing the total number of visits by a given species by the total number of hours of observations. We also recorded postfeeding flight distances of birds departing of focal plants until the first landing (perch) as an estimate of dispersal distance (Jordano and Schupp, 2000), in which we used intervals of distance $(0-1.9 ; 2-4.9 ; 5-9.9 ; 10-19.9 ; 20-39.9 ;>40 \mathrm{~m})$. Although birds could not be followed to greater distances due to visual obstruction by the vegetation, seed retention time in the gut probably allows longer dispersal distances (Christianini and Oliveira, 2010).

The consumption of pulp was defined as: picking $(\mathrm{P})$, reaching $(\mathrm{R})$, hanging $(\mathrm{Ha})$, and in-flight $(\mathrm{F})$, according to Moermond and Denslow (1985). Classifications of bird species according to their diet follows Motta-Junior (1990), Sick (1997), and Santos (2004). Classification and taxonomic nomenclature of species follows CBRO (2011).

We investigated experimentally the effect of seeds passage through the digestive tract of birds. The experiment was composed of two treatments: (i) seeds of the control group ( $\mathrm{N}=200$ seeds) and, (ii) seeds dispersed by birds $(\mathrm{N}=202$ seeds). The seeds of the control group were directly removed from fruits of five different plants, washed and placed in Petri dishes, so that each Petri dish had seeds of five plants. Aiming to capture the dispersers, in order to obtain dispersed seeds were used mist nets installed next to fruiting individuals of $C$. jamacaru. The mist nets were installed in the fruiting peak of $C$. jamacaru, from 05:00 to 17:00 h, totaling 8 days with 96 hours of effort. Captured birds were kept in cotton holding bags for 10-20 min prior to release and any feces produced were collected. Seeds found in the feces were washed, counted and identified using a stereo microscope and compared to a seed reference collection.

For each treatment, seeds were placed on Petri dishes covered with two layers of filter paper moistened with distilled water, which remained in germination chambers under optimal conditions for the study species $\left(30^{\circ} \mathrm{C}\right.$ and $12 \mathrm{~h}$ photoperiodo) according to Meiado et al. (2010). There were eight dishes per treatment, using 25 seeds in each Petri dish. Dishes were sealed with transparent masking tape. No solution was added into the Petri dishes during the assessment period. Radicle protrusion was considered to be the criteria for germinated seeds, and was assessed daily over a 30 -day period.

Germination was defined as the time when the radicle tip emerged $\geq 1 \mathrm{~mm}$ from the seeds coat. For each seed germination treatment, we calculated germinability (\%) and mean germination time $\left(t=\sum n i . t i / \sum n i\right)$, where $t i$ is the period from the start of the experiment to the $i^{\text {th }}$ observation (day) and $n i$ is the number of seeds germinated in the time $i$, according to Ranal and Santana (2006).

\subsection{Statistical analysis}

Spearman's rank correlations were calculated between the monthly values of fruiting and rainfall and temperatures during the study year. The climate data of temperature and rainfall were obtained by Agência Executiva de Gestão das Águas do Estado da Paraíba - AESA, and collected at Estação de São José dos Cordeiros, the municipality where is located the study site. The Spearman coefficient was also used to determine the relationship between the numbers of visits and the quantities of mature fruits. Differences in germination parameters among treatments were tested for statistical significance using a Student $t$ test. All statistical analyses were carried out using the program Statistica $10.0(p<0.05)($ StatSoft, 2010).

\section{Results}

A total of 200 fruits were produced by fifteen C. jamacaru individual during the field work, with $85 \%(\mathrm{~N}=171)$ being unripe and $15 \%(\mathrm{~N}=29)$ ripe. The months of peak fruiting occurred during June/2009 and February/2010 (Figure 1). Fruiting peak was considered when most of the cactus plants produced the greatest number of ripe fruits. The Augspurger Synchrony Index was 0.79, indicating the predominance of simultaneous offerings of fruits $C$. jamacaru individuals for frugivorous birds. Cereus jamacaru present an annual fruiting pattern (sensu Newstrom et al., 1994), producing fruits during the period 
of greatest rainfall (Figure 1), this fruiting demonstrated a positive correlation with precipitation ( $\mathrm{rs}=0.59$; $\mathrm{p}<0.05)$; however, no significant correlation was noted between fruiting and temperature ( $\mathrm{rs}=0.35 ; \mathrm{p}<0.05)$.

Fruits are fleshy and dehiscent, with $69.64 \pm 5.45$ $\times 49.62 \pm 3.24 \mathrm{~mm}$, having on average $383 \pm 24$ black seeds that measured $2.77 \pm 0.8 \times 1.98 \pm 0.6 \mathrm{~mm}$, and which are immersed in an aqueous white pulp. The fruit of $C$. jamacaru require approximately 20 days to mature, crack, and expose its pulp and seeds. The fruits remain open for approximately 3 days and dropping after this period.

During this period the white pulp can be partially or totally removed by birds from each individual fruit. Fruit dehiscence occurred mostly between 07:00 and 11:00, coinciding with the hours of greatest visiting frequency and greatest diversity of bird species consuming the fruits (Figure 2). The intensity of visits was reduced during the warmest hours of the day. The correlation between the

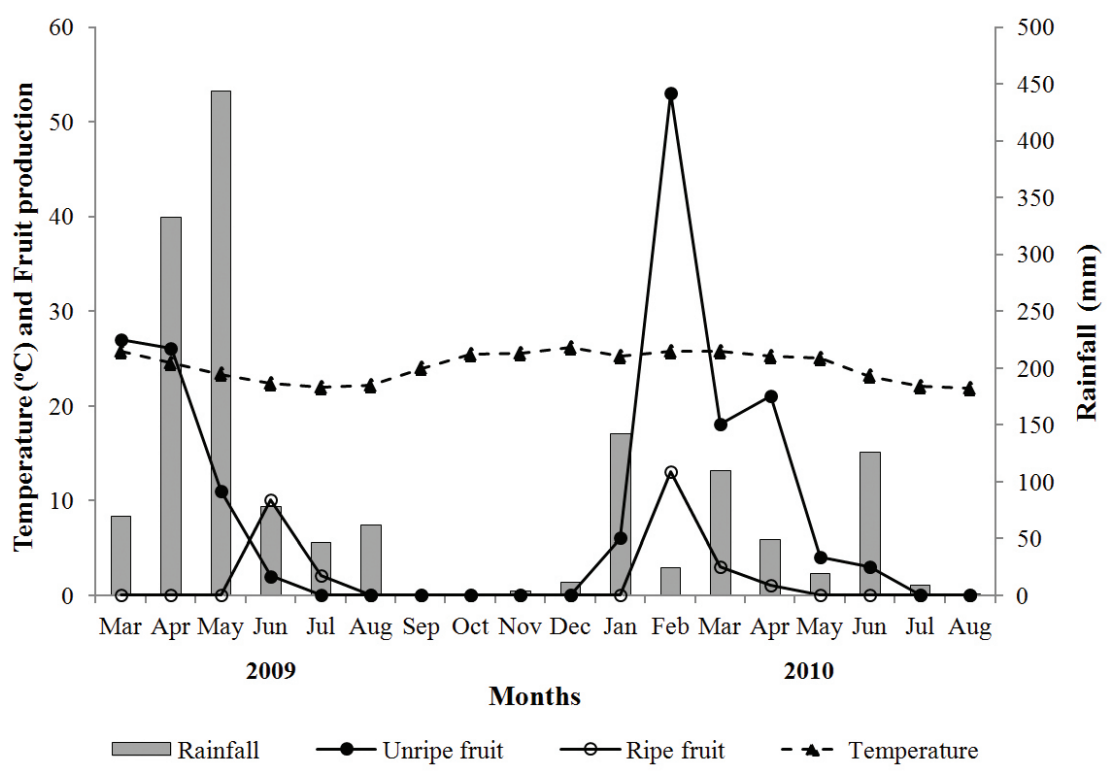

Figure 1. Production of unripe and ripe fruits by Cereus jamacaru DC. ssp. jamacaru from March/2009 to August/2010 at the PNR Fazenda Almas - Paraíba state, Brazil. The climate data of temperature and rainfall were obtained by Agência Executiva de Gestão das Águas do Estado da Paraíba - AESA, and collected at Estação de São José dos Cordeiros.

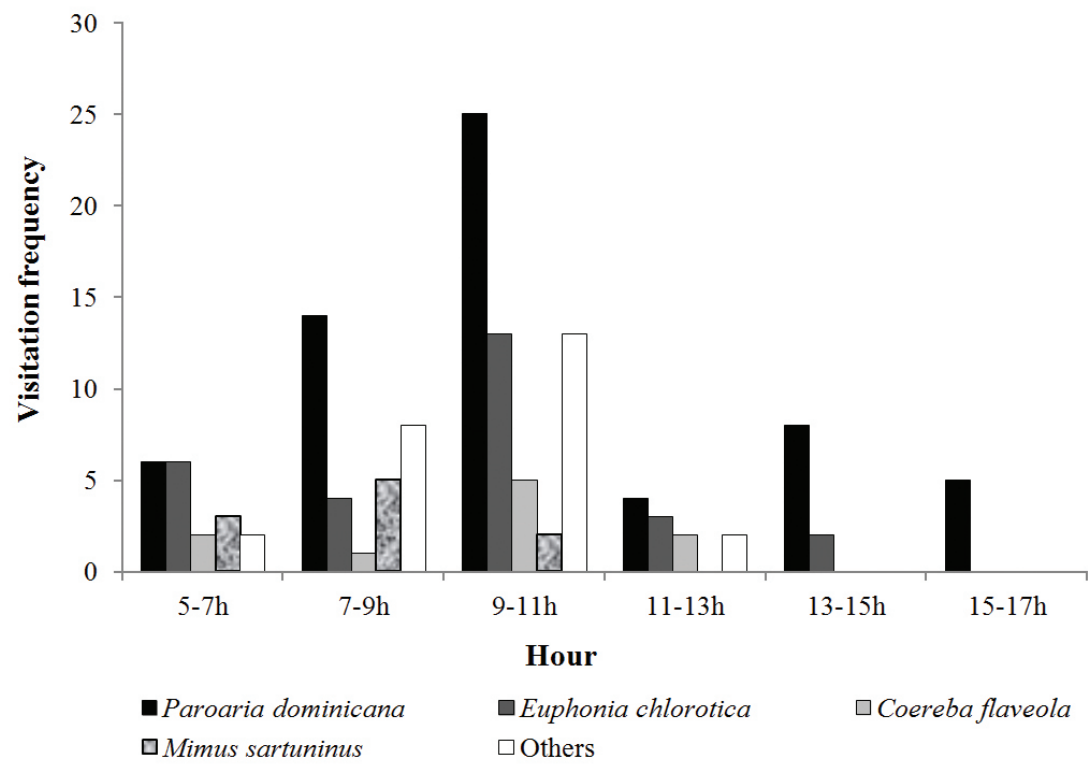

Figure 2. Visitation frequency of seeds dispersers of Cereus jamacaru DC. ssp. jamacaru during the whole day at the PNR Fazenda Almas - Paraíba state, Brazil. 
number of visits and the quantities of exposed fruits was positive $(r s=0.69 ; p<0.05)$, what implies that a larger number of fruits ready to be dispersed can attract a greater number of frugivores.

A total of 135 visits involving nine species of resident birds were recorded along $148 \mathrm{~h}$ of focal observations (Table 1). During these visits, more than one fruit on the same individual could be visited by the same frugivore, such that a larger number of mature fruits on any given cactus individual would result in a greater number of visits to that plant. No visits to any of the fruits were observed during rainy days or at night.

The birds stayed in the cactus fruits according to the quantity of available pulp. The average time required to remove all fruit pulp was approximately 4 hours (after initial exposition), although this was, of course, dependent on the visitation frequency. Length of bird visits varied from 15 seconds to 4 min (Table 1). The most frequent visiting bird species were Paroaria dominicana and Euphonia chlorotica, representing $49 \%$ and $16 \%$ of the total numbers of visitors respectively.

Most birds swallowed intact seeds and were observed utilizing "picking" as foraging behavior of pulp. The large size of C. jamacaru fruits make them great as a landing platform for birds. Thereby, frugivorous could support themselves on the fruit structure, inclining their bodies forward and downwards, removing the succulent pulp using their beaks, and swallow it together with the seeds. The species Lanio pileatus and Machetornis rixosa only consumed fruits that had fallen to the ground. On various occasions ( $\mathrm{N}=28$ records) birds were observed visiting C. jamacaru individuals and carrying away pulp in their beaks, presumably to feed their offsprings.

Seeds removed by birds travelled $10.6 \pm 11.2 \mathrm{~m}$ $(\mathrm{N}=102$ records) until dispersers make the first landing perch. We observed that seeds were discarded in all intervals of distances. The categories with the greatest proportions of seeds discarded were 5-9.9; $10-19.9$ with $35 \%$ and $40 \%$, respectively. Lanio pileatus and Icterus jamacaii were the species responsible for the longer dispersal distance, $28 \mathrm{~m}$ and $>40 \mathrm{~m}$, respectively. When visiting the fruits, the birds knocked down part of the pulp containing seeds beneath the parent plant ( $\mathrm{N}=16$ records), making it available for secondary dispersers (lizards and ants).

Five out of nine species of birds that were observed eating fruits of $C$. jamacaru were captured in mist nets. It was collected a total of 202 seeds in their feces. The species that were captured were $P$. dominicana $(\mathrm{N}=86$ seeds; four captures), E. chlorotica $(\mathrm{N}=41$ seeds; three captures), I. jamacaii ( $\mathrm{N}=29$ seeds; three captures), Coereba

Table 1. Bird species observed visiting Cereus jamacaru DC. ssp. jamacaru. Data represents $148 \mathrm{~h}$ of observations. All bird species were Caatinga residents and show "picking" as their consumption tactic of pulp. Bird classifications and taxonomic nomenclature follow CBRO (2011) and diet is assigned according to Motta-Junior (1990), Sick (1997), and Santos (2004).

\begin{tabular}{|c|c|c|c|c|c|}
\hline Family/Species & $\begin{array}{l}\text { Number } \\
\text { of visits }\end{array}$ & $\begin{array}{c}\text { Average duration } \\
\text { of visits (a) }\end{array}$ & Diet (b) & $\begin{array}{c}\text { Visitation } \\
\text { frequency (visits } / h \text { ) }\end{array}$ & $\begin{array}{c}\text { Average dispersal } \\
\text { distance (c) }\end{array}$ \\
\hline $\begin{array}{l}\text { Picidae } \\
\text { Veniliornis passerinus } \\
\text { Reichenbach } 1845\end{array}$ & 3 & $120 \pm 30$ & INS & 0.02 & $14 \pm 5$ \\
\hline $\begin{array}{l}\text { Furnariidae } \\
\text { Pseudoseisura cristata } \\
\text { Spix } 1824\end{array}$ & 5 & $35 \pm 12$ & INS & 0.03 & $12 \pm 8$ \\
\hline $\begin{array}{l}\text { Tyrannidae } \\
\text { Machetornis rixosa } \\
\text { Vieillot } 1819\end{array}$ & 5 & $22 \pm 10$ & INS & 0.03 & $19 \pm 4$ \\
\hline $\begin{array}{l}\text { Mimidae } \\
\text { Mimus saturninus } \\
\text { Lichtenstein } 1823\end{array}$ & 10 & $18 \pm 5$ & $\mathrm{OMN}$ & 0.06 & $15 \pm 6$ \\
\hline $\begin{array}{l}\text { Coerebidae } \\
\text { Coereba flaveola } \\
\text { Linnaeus } 1758\end{array}$ & 10 & $20 \pm 8$ & $\mathrm{OMN}$ & 0.06 & $18 \pm 3$ \\
\hline $\begin{array}{l}\text { Thraupidae } \\
\text { Lanio pileatus Wied } 1821\end{array}$ & 8 & $30 \pm 5$ & GRA & 0.05 & $24 \pm 6$ \\
\hline$\frac{\text { Paroaria dominicana }}{\text { Linnaeus } 1758}$ & 62 & $210 \pm 20$ & GRA & 0.41 & $18 \pm 4$ \\
\hline $\begin{array}{l}\text { Icteridae } \\
\text { Icterus jamacaii Gmelin } 1788\end{array}$ & 4 & $45 \pm 8$ & FRU & 0.02 & $25 \pm 8$ \\
\hline $\begin{array}{l}\text { Fringillidae } \\
\text { Euphonia chlorotica } \\
\text { Linnaeus } 1766\end{array}$ & 28 & $180 \pm 6$ & $\mathrm{OMN}$ & 0.18 & $12 \pm 9$ \\
\hline
\end{tabular}

(a) Average duration of the visits, in seconds (average \pm standard deviation); (b) FRU = frugivorous, INS= insectivorous, $\mathrm{OMN}=$ omnivorous, GRA= granivorous; (c) Average dispersal distance, in meters (average \pm standard deviation). 
flaveola $(\mathrm{N}=28$ seeds; two captures), L. pileatus $(\mathrm{N}=18$ seeds; one capture).

Germination tests show that the birds had a high quantity of viable seeds. Approximately $87 \%$ (N=175 seeds) found in feces germinate under optimal conditions. No significant difference was found among the germinability of seeds of the control group and those defecated by birds $(t=1.45 ; p=0.16)$. However, the seeds dispersed by birds showed lowest mean germination time ( $4 \pm 1$ days) related to the control group $(6 \pm 2)$, with significant differences $(p=0.0002)$, which accelerated the germination process.

\section{Discussion}

C. jamacaru fruits present characteristics indicating ornithochory as their dispersion syndrome (as is common by cactus species) (Silva, 1988; León de la Luz and Domínguez, 1991; Silvius, 1995; Soriano et al., 1999; Ruiz et al., 2000; Godinez-Alvarez et al., 2002; Naranjo et al., 2003; Carlos Rengifo et al., 2007) and represent an important food resource for the avifauna. Due the high fruit production of these plants and elevated sinchronicity, a high proportion of fruits are available daily during the ripening period, and the high synchrony limit the supply of the resource to a short period of time. These features, found in $C$. jamacaru, presumably influenced the enhancement in fruit consumption by several birds species in this highly seasonal ecosystem.

In this study, we recorded nine species of birds that use the C. jamacaru fruits as food resource. Compared with the available lists of birds associated with columnar cacti in other Neotropical arid ecosystem (Silvius, 1995; León de la Luz and Domínguez, 1991; Soriano et al., 1999; Ruiz et al., 2000; Godinez-Alvarez et al., 2002; Naranjo et al., 2003; Carlos Rengifo et al., 2007), the Caatinga showed a bird community with the same richness. Likewise, compared with the results found in Atlantic Rainforest by Silva (1988), the list of frugivorous birds associated with C. jamacaru fruits, also showed similar species composition, visitor behavior and temporal pattern of visits. The period of greatest activity for most birds and the greatest dehiscence of Cereus spp. fruits occur in the morning hours demonstrating close similarities between the dispersers that feed by cactus species of the same genus.

Araujo (2009) in an earlier study of bird reproduction in the same study site indicated that the reproductive activities of the local bird communities are positive and highly significant correlated with rainfall, as was also observed with fruiting pattern of $C$. jamacaru. The two avian activities that require the greatest energy expenditures are reproduction and molting. In this period, birds supplement their diet with other sources available (Davis, 1945; Poulin et al., 1992). Most cactus fruits are water and carbohidrate rich, and low in protein and lipids, thus, consumers would probably need to ingest either a large volume of fruit or else suplement their diet with arthropods and other plant parts to meet their nutritional requirements (Silva, 1988; Velez Boza and Velez, 1990).
Bahia et al. (2010) evaluated chemical characteristics of C. jamacaru, and identified in the fruit pulp a high lipid content (12.43\%), high sugar content (10.42\%) and water. The high value of lipid is associated mainly in the seed which were not removed of pulp for analysis. Araujo (2009) identified Cactaceae as having the greatest number of species providing energetic resources for birds in an area of Caatinga vegetation. Araujo (2009) found Cactaceae seeds (C. jamacaru and Pilosocereus spp.) in the feces and stomach contents of L. pileatus, together with large quantities of insects. Further studies should be performed aiming to assess the lipid profile of the fruit, since the reserves of the endosperm of the seeds can be consumed by birds, especially granivorous.

The species I. jamacaii, Veniliornis passerinus, Pseudoseisura cristata and M. rixosa, reported here, are new dispersal agents for the family Cactaceae. P. dominicana, L. pileatus, M. saturninus, E. chlorotica, and C. flaveola were previously characterized as dispersers of Cactaceae (Silva, 1988; Silvius, 1995; Soriano et al., 1999; Ruiz et al., 2000; Godinez-Alvarez et al., 2002; Naranjo et al., 2003; Carlos Rengifo et al., 2007). Our observations indicated that $P$. dominicana and E. chlorotica were among the most frequent visitors to $C$. jamacaru and act as potential dispersers, swallowing the whole seeds and defecating intact seeds. All bird species ingested fruit pulp and left the cactus soon after the consumption. Moreover, most of these species ate the pulp in short visits, which reduces the probability of seed defecation or regurgitation under the mother plant (Coates-Estrada and Estrada, 1988).

Examining the removal of fruits and/or seeds by ornithochoric species, dispersal studies should also consider the distances in which the seeds are discarded (Howe and Vande Kerckhove, 1981; Wheelwright, 1991). Differences in habitat use and home ranges may influence the places and distances where plant diaspores may be deposited by birds dispersers (Jordano and Schupp, 2000). Birds that delivered diaspores to distances over $40 \mathrm{~m}$ were effective in removing $C$. jamacaru seeds from near the mother plant, providing the colonization of new sites by species. This effect should be even more pronounced, since gut retention time of diaspores may be much longer than the flight duration to the first perch, enabling birds to carry seeds to longer distances (Christianini and Oliveira, 2010). In some instances, pieces of pulp were dropped under the mother plant, becoming available to ants and lizards. We observed the ant species Dinoponera quadriceps Kempf, 1971 (Ponerinae) removing pulp seeds under the mother plant. This fact corroborates with the results of Leal et al. (2007) that found C. jamacaru seeds being secondarily dispersed by ants. The ants may rescue fallen seeds and provide another chance of dispersal and establishment (Christianini and Oliveira, 2010). These interactions are very important within the dynamics of this cactus species and can directly affect its reproductive success.

The morphological characters of the fruits, such as fleshy red fruits, a succulent white pericarp, and small seeds, favors their consumption by birds and bats. Although 
we have not observed any dispersers visit at night, there is the possibility that small marks left distributed around the fruits have been made by bats, because, we observed the bat species Artibeus lituratus Olfers, 1818 (Chiroptera, Phyllostomidae) visiting Pilosocereus chrysostele (Vaupel) Byles \& G. D. Rowley and Pilosocereus gounellei (F. A. C. Weber) Byles \& Rowley subsp. gounellei (Cactaceae) in the same study site (Gomes, unpubl. data). However, the fact that these marks have been produced by the nails of birds that eat fruit cannot also be discarded.

Seeds dispersed by birds are viable and germinate faster than control group. This indicates that the birds are legitimate dispersers, and that the consumption of $C$. jamacaru fruits by the birds is beneficial for the dispersal of the seeds. Our results are in agreement with those of León de la Luz and Domínguez (1991) and Naranjo et al. (2003), who found that passage of cactus seeds through the digestive tracts of certain birds accelerated the germination process. This can be considered of key importance in semi-arid areas where water is a limiting ecological factor. A decrease in the minimum imbibition time of the seeds should increase the probability of germination in dry forests, likewise, elimination of pulp reduces the risk of depredation and fungal attacks (Naranjo et al., 2003).

Lobova et al. (2003) argue that the seeds that passes through the digestive tract of animals lose the pericarp, that in the soil, serves of substract to fungi and bacteria, in the case of $C$. jamacaru the funicular pulp (Taylor and Zappi, 2004). In this way we can say that one of the benefits of consumption of fruit by the frugivorous birds is the elimination of intact seeds, and probability of establishment in the soil.

It is possible that other species of frugivorous birds observed consuming fruit, also act as $C$. jamacaru dispersers. Although we have not been able to capture them with mist nets to evaluate the effects of seed passage through digestive tract, we believe that these birds are also important as dispersers, either to the consumption of funicular pulp, either mobility associated to the seed, without cause any damaging to them, since the seeds are very small, with the average of $3 \mathrm{~mm}$, which facilitates the passage through the digestive tract of birds. The small size of cactus seed may reduce the possibility that birds act as seed predators.

Besides the potential role of the birds as seed dispersers transporting seeds to long distance and maintaining the high capacity of germination of these seeds and the high seed production per fruit should favor the occurrence and the wide distribution of the C. jamacaru in the study site, if recruitment rates are proportional to the rates of consumption of fruits. P. dominicana and M. saturninus are common in open Caatinga environments, while others, such as L. pileatus and E. chlorotica, are found in both open and dense Caatinga vegetation stands, where C. jamacaru individuals are often abundant (Araujo, 2009). Because Caatinga vegetation and fauna is highly threatened throughout northeastern Brazil (Albuquerque et al., 2012) is important conservation and/ or management of this Cactaceae that serves as resource for resident birds in this ecosystem.

Dispersal system involving birds as dispersers, may also occur in other cacti in other Caatinga areas, pointing out the need for further studies on the reproductive ecology of cacti. In addition to elucidate aspects of the dispersal strategy of C. jamacaru, our results: 1) motivated other about the processes that gave rise such relations with disperser species, as for example: what gave rise to the opening of C. jamacaru fruits during the period of greatest avian activity? 2) identify a number of ecological requirements of the cactus as well as the avifauna that can be used in developing conservation strategies. Furthermore, in our study, the deposition site and consequent plant recruitment was not evaluated. However, it is still not clear which birds deposit seeds in the most appropriate sites for germination and subsequent growth. So, we suggest that this aspects should be investigated. The findings of the present study serve as a starting point for future studies assessing the ecological implications of the dispersal processes that influence functioning of this ecosystem.

Acknowledgements - The authors would like to thank the administrators and workers of the Fazenda Almas for their support during the fieldwork phase. Thanks also to the Conselho Nacional de Desenvolvimento Científico e Tecnológico (CNPq) for an undergraduate scholarship (Programa Institucional de Bolsas de Iniciação Científica - PIBIC/CNPq UFPB) to VGNG through the Projeto PELD Caatinga.

\section{References}

ALBUQUERQUE, UP., ARAUJO, EL., EL-DEIR, ACA., LIMA, ALA., SOUTO, A., BEZERRA, BM., FERRAZ, EMN., FREIRE, EMX., SAMPAIO, EVB., LAS-CASAS, FMG., MOURA, GJB., PEREIRA, GA., MELO, JG., RAMOS, MA., RODAL, MJN., SCHIEL, N., LYRA-NEVES, RM., ALVES, RRN., AZEVEDOJUNIOR, SM., TELINO-JUNIOR, WR. and SEVERI, W., 2012. Caatinga Revisited: Ecology and Conservation of an Important Seasonal Dry Forest. Scientific World Journal, vol. 1, p. 1-18.

ANDERSON, EF., 2001. The Cactus Family. Portland: Timber Press.

ANDRADE, CTS., MARQUES, JGW. and ZAPPI, DC., 2006. Utilização medicinal de cactáceas por sertanejos baianos. Revista Brasileira de Plantas Medicinais, vol. 8, p. 36-42.

ARAUJO, HFP., 2009. Amostragem, Estimativa de Riqueza de Espécies e Variação Temporal na Diversidade, Dieta e Reprodução de Aves em Área de Caatinga, Brasil. João Pessoa: Universidade Federal da Paraíba. 198 p. Tese de Doutorado em Ciências Biológicas (Zoologia).

AUGSPURGER, CK., 1982. A cue for synchronous flowering. In LEIGH, EG., RANH, AS. and WINDSOR, DM. (Eds.). The ecology of a tropical forest. Washington: Smithsonian Institution Press. p. 133-150.

BAHIA, EVA., MORAIS, LRV., SILVA, MP., LIMA, OBV. and SANTOS, SF., 2010. Estudo das características físico-químicas do fruto do mandacaru (Cereus jamacaru DC.) cultivado no sertão pernambucano. In Anais do V Congresso de Pesquisa e Inovação da Rede Norte-Nordeste de Educação Tecnológica, 2010. Maceió. 
BARBOSA, MRV., LIMA, IB., LIMA, JR., CUNHA, JP., AGRA, MF. and THOMAS, WW., 2007. Vegetação e flora no Cariri paraibano. Oecologia Brasiliensis, vol. 11, p. 313-322. http:// dx.doi.org/10.4257/oeco.2007.1103.01

CARLOS RENGIFO, G., NARANJO, ME. and SORIANO, PJ., 2007. Fruit Consumption by Birds and Bats on Two Species of Columnar Cacti in a Semi-Arid Andean Enclave of Venezuela. Caribbean Journal of Science, vol. 43, p. 254-259.

Comitê Brasileiro de Registros Ornitológicos - CBRO. 2011. Listas das aves do Brasil. Available from: <http://www.cbro.org. br/CBRO/listabr.htm>. Access in: 12 Jan 2012.

CHRISTIANINI, AV. and OLIVEIRA, OS., 2010. Birds and ants provide complementary seed dispersal in a neotropical savanna. Journal of Ecology, vol. 98, p. 573-582. http://dx.doi. org/10.1111/j.1365-2745.2010.01653.x

COATES-ESTRADA, R. and ESTRADA, A., 1988. Frugivory and seed dispersal in Cymbopetalum baillonii (Annonaceae) at Los Tuxtlas, Mexico. Journal of Tropical Ecology, vol. 4, p. 157172. http://dx.doi.org/10.1017/S0266467400002650

DAVIS, DE., 1945. The anual cicle of plants, mosquitoes, birds and mammals in two Brazilian forests. Ecological Monographs, vol. 15, p. 243-295. http://dx.doi.org/10.2307/1943247

FREIRE, FCO., 2009. Patógenos Associados ao Mandacaru (Cereus jamacaru DC.) no Estado do Ceará. Embrapa. Comunicado Técnico, no. 148.

GODINEZ-ALVAREZ, H., VALIENTE-BANUET, A. and ROJAS-MARTINEZ, A., 2002. The role of seed dispersers in the population dynamics of the columnar cactus Neobuxbaumia tetetzo. Ecology, vol. 83, p. 2617-2629. http://dx.doi.org/10.1890/00129658(2002)083[2617:TROSDI]2.0.CO;2

GONDIM, MJC., 2001. Dispersão de sementes de Trichilia spp. (Meliaceae) por aves em um fragmento de mata mesófila semidecídua, Rio Claro, SP, Brasil. Ararajuba, vol. 9, p. 101-112.

HERRERA, CM. and JORDANO, P., 1981. Prunus mahaleb and birds: the high-efficiency seed dispersal system of a temperate fruiting tree. Ecological Monographs, vol. 51, p. 203-281. http:// dx.doi.org/10.2307/2937263

HOWE, HF. and SMALLWOOD, J., 1982. Ecology of seed dispersal. Annual Review of Ecology, Evolution, and Systematics, vol. 13, p. 201-228. http://dx.doi.org/10.1146/annurev.es.13.110182.001221

HOWE, HF. and VANDE KERCKHOVE, GA., 1981. Removal of wild nutmeg (Virola surinamensis) crops by birds. Ecology, vol. 62, p. 1093-1106. http://dx.doi.org/10.2307/1937007

JORDANO, P., 1992. Fruits and frugivory. In FENNER, M. (Eds.). Seeds: the ecology of regeneration in plant communities. Wallingford: C.A.B. International. p. 105-155.

JORDANO, P. and SCHUPP, EW., 2000. Determinants of seed disperser effectiveness: the quantity component and patterns of seed rain for Prunus mahaleb. Ecological Monographs, vol. 70, p. 591-615. http://dx.doi.org/10.1890/0012-9615(2000)070[0591:SD ETQC]2.0.CO;2

KÖPPEN, W., 1948. Climatología: con un estudio de los climas de la tierra. Fundo de Cultura Econômica.

LEAL, IR., WIRTH, R. and TABARELLI, M., 2007. Seed dispersal by ants in semi-arid Caatinga of Northeast Brazil. Annals of Botany, vol. 99, p. 885-894. PMid:17430980 PMCid:PMC2802904. http:// dx.doi.org/10.1093/aob/mcm017
LEÓN DE LA LUZ, JL. and DOMÍNGUEZ, R., 1991. Evaluación de la reproducción por semilla de la pitaya agria (Stenocereus gummosus) en Baja California Sur, Mexico. Acta Botanica Mexicana, vol. 14, p. 75-87.

LOBOVA, TA., MORI, SA., BLANCHARD, F., PECKHAM, H. and CHARLES-DOMINIQUE, P., 2003. Cecropia as a food resource for bats in French Guiana and the significance of fruit structure in seed dispersal and longevity. American Journal of Botany, vol. 90, p. 388-403. PMid:21659132. http://dx.doi. org/10.3732/ajb.90.3.388

MEIADO, MV., ALBUQUERQUE, LSC., ROCHA, EA., ROJAS-ARÉCHIGA, M. and LEAL, IR., 2010. Seed germination responses of Cereus jamacaru DC. ssp. jamacaru (Cactaceae) to environmental factors. Plant Species Biology, vol. 25, p. 120-128. http://dx.doi.org/10.1111/j.1442-1984.2010.00274.x

MOERMOND, TC. and DENSLOW, JS., 1985. Neotropical avian frugivores: patterns of behavior, morphology, and nutrition, with consequences for fruit selection. Ornithological Monographs, vol. 36 , p. $865-897$.

MOTTA-JUNIOR, JC., 1990. Estrutura trófica e composição das avifaunas de três habitats terrestres na região central do estado de São Paulo. Ararajuba, vol. 1, p. 65-71.

NARANJO, ME., RENGIFO, G. and SORIANO, PJ., 2003. Effect of ingestion by bats and birds on seed germination of Stenocereus griseus and Subpilocereus repandus (Cactaceae). Journal of Tropical Ecology, vol. 19, p. 19-25.

NEWSTROM, LE., FRANKIE, GW. and BAKER, HG., 1994. A new classification for plant phenology based on flowering patterns in lowland tropical rain forest trees at La Selva, Costa Rica. Biotropica, vol. 26, p. 141-159. http://dx.doi.org/10.2307/2388804

PASCOTTO, MC., 2006. Avifauna dispersora de sementes de Alchornea glandulosa (Euphorbiaceae) em uma área de mata ciliar no estado de São Paulo. Revista Brasileira de Ornitologia, vol. 14, p. 291-296.

PETIT, S., 2001. The reproductive phenology of three sympatric species of columnar cacti on Curaçao. Journal of Arid Environments, vol. 49, p. 521-531. http://dx.doi.org/10.1006/jare.2001.0801

POULIN, B., LEFEBVRE, G. and MCNEILL, R., 1992. Tropical avian phenology in relation to abundance and exploitation of food resources. Ecology, vol. 73, p. 2295-2309. http://dx.doi. org/10.2307/1941476

PRADO, DE., 2003. As Caatingas da América do Sul. In LEAL, IR.; TABARELLI, M. and SILVA, JMC. (Orgs.). Ecologia e conservação da Caatinga. Recife: Editora UFPE. p. 3-74.

QUIRINO, ZGM., 2006. Fenologia, Síndromes de Polinização e Dispersão e Recursos Florais de uma Comunidade de Caatinga no Cariri Paraibano. Recife: Universidade Federal de Pernambuco. 164 p. Tese de Doutorado em Biologia Vegetal.

RANAL, MA. and SANTANA, DG., 2006. How and why to measure the germination process? Revista Brasileira de Botânica, vol. 29 , p. 1-11.

RODAL, MJN. and SAMPAIO, EVSB., 2002. A vegetação do bioma Caatinga. In SAMPAIO, EVSB., GIULIETTI, AM., VIRGÍNIO, J. and ROJAS, CFLG. (Org.). Vegetação e flora da Caatinga. Recife. p. 11-24.

RUIZ, A., SANTOS, M. and CAVELIER, J., 2000. Estudio Fenológico de Cactáceas em El Enclave seco de La Tatacoa, Colombia. Biotropica, vol. 3, p. 397-407. 
SANTOS, MPD., 2004. As comunidades de aves em duas fisionomias da vegetação da Caatinga no Piauí. Ararajuba, vol. 13, p. 104-110.

SICK, H., 1997. Ornitologia brasileira. Rio de Janeiro: Nova Fronteira.

SILVA, WR., 1988. Ornitocoria em Cereus peruvianus (Cactaceae) na Serra do Japi, estado de São Paulo. Revista Brasileira de Biologia $=$ Brazilian Journal of Biology, vol. 48, p. 381-389.

SILVIUS, KM., 1995. Avian consumers of Cardón fruits (Stenocereus griseus: Cactaceae) on Margarita Island, Venezuela. Biotropica, vol. 27, p. 96-105. http://dx.doi.org/10.2307/2388907

SORIANO, PJ., NARANJO, ME., RENGIFO, C., FIGUERA, M., RONDON, M. and RUIZ, RL., 1999. Aves consumidoras de frutos de Cactáceas columnares Del enclave semiárido de Lagunillas, Mérida, Venezuela. Ecotropicos, vol. 12, p. 91-100.

SOSA, M., 1991. Relaciones ecológicas entre el murciélago Glossophaga longirostris y las cactáceas columnares en el bolsón árido de Lagunillas, Mérida, Venezuela. Mérida: Universidad de Los Andes, Facultad de Ciencias, Departamento de Biología. 106 p. Trabajo especial de grado.

TAYLOR, NP. and ZAPPI, DC., 2004. Cacti of Eastern Brazil. Royal Botanic Gardens, Kew.
TERBORGH, J., 1986. Community aspects of frugivory in tropical forests. In ESTRADA, A. and FLEMING, TH. (Eds.). Frugivores and seed dispersal. Dordrecht: W. Junk Publishers. p. 371-384. http://dx.doi.org/10.1007/978-94-009-4812-9_32

VAN DER PIJL, L., 1982. Principles of dispersal in higher plants. Berlín: Springer-Verlag. 215 p. http://dx.doi.org/10.1007/9783-642-87925-8

VELEZ BOZA, F. and VELEZ, GV., 1990. Plantas alimenticias de Venezuela. Caracas: Fundacion Bigott y Sociedad de Ciencias Naturales La Salle. Monografia, no. 37.

WENNY, DG. and LEVEY, DJ., 1998. Directed seed dispersal by bellbirds in a tropical cloud forest. Proceedings of the National Academy of Sciences, vol. 95, p. 6204-6207. PMid:9600942 PMCid:PMC27627.

WHEELWRIGHT, NT., 1991. How long do fruit-eating birds stay in the plants where they feed? Biotropica, vol. 23, p. 29-40. 